\title{
Anoxic and aerobic values for the yield coefficient of the heterotrophic biomass: Determination at full-scale plants and consequences on simulations
}

\author{
J-M Choubert ${ }^{1 *}$, A Marquot ${ }^{2,3}$, A-E Stricker ${ }^{2,4}$, Y Racault ${ }^{2}$, S Gillot ${ }^{5}$ and A Héduit ${ }^{5}$ \\ ${ }^{1}$ Cemagref, UR QELY, 3 bis quai chauveau - CP 220, F-69336 Lyon cedex 9, France \\ ${ }^{2}$ Cemagref, F-33612 Cestas, France \\ ${ }^{3}$ WTSim SARL, 15 impasse Fauré, F-33000 Bordeaux, France \\ ${ }^{4}$ Environment Canada, 867 Lakeshore Road, Burlington - Ontario L7R 4A6, Canada \\ ${ }^{5}$ Cemagref, F-92163 Antony, France
}

\begin{abstract}
The present study aims at optimising the nitrification and denitrification phases at intermittently aerated process (activated sludge) removing nitrogen from municipal wastewater. The nitrogen removal performance recorded at 22 intermittently aerated plants was compared to the results obtained from the simulations given by the widely used ASM1. It is shown that simulations with a single value for the heterotrophic yield with any electron acceptor over-predict the nitrate concentration in the effluent of treatment plants. The reduction of this coefficient by $20 \%$ for anoxic conditions reduces the nitrate concentration by $10 \mathrm{~g} \mathrm{~N} \cdot \mathrm{m}^{-3}$. It significantly improves the accuracy of the predictions of nitrate concentrations in treated effluents compare to real data.

Simulations with dual values (aerobic and anoxic conditions) for heterotrophic yield (modified ASM1) were then used to determine the practical daily aerobic time interval to meet a given nitrogen discharge objective. Finally, to support design decisions, the relevance of a pre-denitrification configuration in front of an intermittently aerated tank was studied. It is shown that when the load of $\mathrm{BOD}_{5}$ is below the conventional design value, a small contribution of the anoxic zone to nitrate removal occurs, except for over-aerated plants. When plants receive a higher load of $\mathrm{BOD}_{5}$, the modified ASM1 suggests that the anoxic zone has a higher contribution to nitrogen removal, for both correctly and over-aerated plants.
\end{abstract}

Keywords: activated sludge, denitrification rate, anoxic heterotrophic growth yield, low temperature, modelling

\section{Introduction}

Due to the ability of most heterotrophic micro-organisms to utilise nitrate as electron acceptor in anoxic conditions, intermittently aerated processes can achieve a significant nitrate conversion into $\mathrm{N}_{2}$ gas (denitrification). Nitrate produced from the conversion of ammonia during the aeration phase (nitrification) is removed this way at very low oxygen concentrations, provided that carbon substrate is present. This is the case when raw influent with a $\mathrm{C} / \mathrm{N}$ ratio in the range 3.5 to $4.5 \mathrm{~g} \mathrm{COD} \cdot \mathrm{g} \mathrm{N}^{-1}$ (Henze, 1996) is applied to activated sludge. The denitrification rate depends on 3 main factors:

- The concentrations of readily biodegradable COD

- The absence of dissolved oxygen

- The concentration of nitrate.

To describe this limitation, Monod laws including the following half-saturation coefficients are used to express the instant denitrification rate: $\mathrm{K}_{\mathrm{s}}=30 \mathrm{~g} \mathrm{COD} \cdot \mathrm{m}^{-3}, \mathrm{~K}_{\mathrm{OH}}=0.2 \mathrm{~g} \mathrm{O}_{2} \cdot \mathrm{m}^{-3}$, and $\mathrm{K}_{\mathrm{NO}}=1 \mathrm{~g} \mathrm{~N} \cdot \mathrm{m}^{-3}$ (Henze et al., 1987). Unfortunately, this parameter varies during a $24 \mathrm{~h}$ period, and practitioners utilise an

\footnotetext{
* To whom all correspondence should be addressed.

푱 +33 (0)4 722089 04; fax: +33 (0)4 784778 75; e-mail: jean-marc.choubert@cemagref.fr

Received 15 April 2008; accepted in revised form 15 October 2008
}

average value of the denitrification rate for design. Reported values of the average denitrification rate are in the range of 0.5 to $2.1 \mathrm{mg} \mathrm{N} \cdot(\mathrm{g} \text { MLVSS } \cdot h)^{-1}$ for municipal wastewaters (Henze et al., 1987; Hoffman and Kute, 1990; Orhon et al., 1998; ATVDVWK-A_131E, 2000; FNDAE_25, 2002; Metcalf and Eddy, 2005). Reported values with synthetic carbon source containing volatile fatty acids are in the same range as the one observed with true wastewater (Elefsiniotis and $\mathrm{Li}, 2006$ ), whereas synthetic carbon sources like methanol and ethanol provide denitrification rate values in the range of 2.5 to $25 \mathrm{mg}$ $\mathrm{N} \cdot(\mathrm{g} \text { MLVSS } \cdot h)^{-1}$ (Henze et al., 1987; Carrera et al., 2003; Foglar and Briski, 2003). These rates are often obtained on a daily scale through a nitrogen mass-balance approach applied to daily composite samples with a daily denitrification time assessed from a redox probe: The redox potential quickly decreases at the end of the denitrification phase (turning point). Nevertheless, the estimation of the denitrification time can be inaccurate due to the natural alteration of the redox signal when the electrode is not regularly cleaned.

In order to meet an ammonia concentration in treated water of below $5 \mathrm{~g} \mathrm{~N} \cdot \mathrm{m}^{-3}$ even in winter conditions, the conventional design guidelines suggest limiting the applied food-to-micro-organism ratio $(\mathrm{F} / \mathrm{M})$ to $0.10 \mathrm{~kg} \mathrm{BOD}_{5} \cdot(\mathrm{kg}$ MLVSS $\cdot \mathrm{d})^{-1}$ (sludge retention time (SRT) over $20 \mathrm{~d}$ ). It is also recommended applying a daily aerobic time of approximately $14 \mathrm{~h}$ a day, providing at least $2 \mathrm{~g} \mathrm{O}_{2} \cdot \mathrm{m}^{-3}$ during the 
aeration periods to maintain low-growth rate nitrifying bacteria (FNDAE_25, 2002; Choubert et al., 2005a). These technical rules provide a nitrogen discharge in accordance with the objectives of the European Directive 91/271/EEC (1991) requiring a high nitrogen removal efficiency from wastewaters above a temperature of $12^{\circ} \mathrm{C}$ : a total nitrogen discharge objective below $15 \mathrm{gN} \cdot \mathrm{m}^{-3}$ is required in treated effluent. To meet this objective, a total nitrogen target (ex: ammonia + nitrate below $10 \mathrm{~g} \mathrm{~N} \cdot \mathrm{m}^{-3}$ ) is often required.

However, in order to meet a total nitrogen discharge objective (ex: ammonia + nitrate below $10 \mathrm{~g} \mathrm{~N} \cdot \mathrm{m}^{-3}$, as required for more and more treatment plants), the empirical design rule considers that an un-aerated time period of $10 \mathrm{~h} \cdot \mathrm{d}^{-1}$ is necessary. Nevertheless, actual operating conditions often provide more aerobic time (i.e. a higher aerated mass fraction) than necessary, with possible high nitrate concentrations in the effluent. It is therefore necessary to determine an operating window providing the correct daily aerobic and anoxic times to achieve nitrification and denitrification in the same tank. To build such an operating window, the Activated Sludge Model No 1 (ASM1 Henze et al., 1987) is a useful tool. However, simulation results need to correspond closely to reality in order to determine the best operating conditions for given ammonia and nitrate concentration targets in the effluent, otherwise it is difficult to optimise the process.

Recent studies have shown that some of the default parameter values proposed in ASM1 needed to be reconsidered to correctly predict nitrogen removal performances (Dold et al., 2005; Choubert et al., 2008). These results particularly influence the optimal operating conditions like the aeration time. For the heterotrophic biomass, the stoichiometric ratio which determines the proportion of substrate that is utilised for the synthesis of new cell mass $\left(\mathrm{Y}_{\mathrm{H}}\right)$ was found to be too high in anoxic conditions (Muller et al., 2003). Different studies consisting mainly of respirometric batch test protocols applied to various activated sludges (respirometric laboratory experiments) have proposed a heterotrophic anoxic yield $\left(\mathrm{Y}_{\mathrm{H} \text {, anox }}\right)$ of $0.54 \mathrm{gCOD}_{\text {produced }} / \mathrm{gCOD}_{\text {removed }}$ (Sozen et al., 1998; Spérandio et al., 1999; Strotmann et al., 1999; Foglar and Briski, 2003). The authors recommend the use of this value for anoxic conditions, instead of using the more 'conventional' value of $0.67 \mathrm{gCOD}_{\text {produced }} \cdot \mathrm{gCOD}_{\text {removed }}^{-1}$ (Henze et al., 1987). Batch test protocols suggest that the latter value should be used for aerobic conditions only. Nevertheless, no validation of this change has yet been demonstrated, and the old set of parameters is still used in current modelling projects not just by practitioners but also in research applications (Jiang et al., 2005, Choubert et al., 2005b; Spérandio et al., 2008; Benchmark).

When $\mathrm{Y}_{\mathrm{H}}=0.54 \mathrm{~g} \mathrm{COD}_{\text {produced }} \cdot \mathrm{g} \mathrm{COD}_{\text {removed }}{ }^{-1}$, the yield of nitrate consumption is $\left(1-\mathrm{Y}_{\mathrm{H}}\right) / 2.86=0.161 \mathrm{~g} \mathrm{NO}_{3}^{-}-\mathrm{N}$ per $\mathrm{g} \mathrm{COD}$ removed, instead of $0.115 \mathrm{~g} \mathrm{NO}_{3}^{-}-\mathrm{N}$ with $\mathrm{Y}_{\mathrm{H}}=0.67$ (Muller et al., 2003). This $40 \%$ increase of the nitrate consumption yield is caused by the $\mathrm{Y}_{\mathrm{H}}$ decrease by $20 \%$, which lowers the simulated nitrate concentrations in the effluent. Such a modification is suggested in ASM3 (Gujer et al., 1999; Henze et al., 2000). Nevertheless, the need to integrate this modification was not clearly demonstrated with full-scale data.

Considering that experimental data quantifying the reduction of the heterotrophic yield from aerobic to anoxic conditions with wastewater were mainly obtained with batch-tests protocols, verification was initiated at full scale plants. The data collected at 22 intermittently aerated plants were used. To validate the reduction of the heterotrophic anoxic yield, the nitrogen-removal performances were studied using a nitrogen mass balance method, and also with simulations using first the original ASM1 matrix, and then a modified one. Two different configurations (single aeration tank and single aeration tank with a pre-denitrification tank) were considered to study the practical consequences of using the default or the reduced $\mathrm{Y}_{H}$ value in anoxic condition (modified ASM1 matrix). Initially, simulations were used to compare the optimum values of the daily aerobic time for a nitrogen discharge objective of $10 \mathrm{~g} \mathrm{~N} \cdot \mathrm{m}^{-3}$. In a second step, the performances of both layouts were compared, and the relevance of the predenitrification design was critically assessed for different $\mathrm{F} / \mathrm{M}$ ratios.

\section{Material and methods}

\section{Investigations at full-scale treatment plants}

22 French biological nutrient removal treatment plants with a treatment capacity of between 600 and 65000 population equivalents (tank volume of 65 and $17900 \mathrm{~m}^{3}$ respectively) were investigated at low temperature. The temperatures of the mixed liquor of these WWTPs were in the range 8 to $12^{\circ} \mathrm{C}$. All of them were conventionally designed with intermittent aeration and an $\mathrm{F} / \mathrm{M}$ ratio below $0.10 \mathrm{~kg} \mathrm{BOD} \cdot(\mathrm{kg} \mathrm{MLVSS} \cdot \mathrm{d})^{-1}$ for both nitrification and denitrification.

The following parameters were monitored according to European (NF EN) or international (ISO) standardised analysis techniques: Inflow rates, influent and effluent daily average concentrations $\left(\mathrm{BOD}_{5}, \mathrm{COD}, \mathrm{TKN}, \mathrm{NH}_{4}^{+}-\mathrm{N}, \mathrm{NO}_{3}^{-}-\mathrm{N}, \mathrm{TSS}\right.$, VSS), aerobic time and concentrations in the aeration tank (MLVSS, dissolved oxygen). For the chemical analysis of the concentrations of the nitrogen forms (nitrate and ammonia), a 7\% accuracy is expected.

The $\mathrm{F} / \mathrm{M}$ ratios ranged from 0.03 to $0.07 \mathrm{~kg} \mathrm{BOD}_{5} \cdot(\mathrm{kg}$ MLVSS $d)^{-1}$, with corresponding SRT from 60 down to $20 \mathrm{~d}$. The $\mathrm{COD} / \mathrm{BOD}_{5}$ ratio measured on the influents of the 22 facilities was 0.38 on average ( 0.3 to 0.5 for extreme values).

Of the 22 facilities, 13 have single aeration tanks and 9 include a pre-anoxic zone containing $20 \%$ of the biological sludge volume, with a mixed liquor return ratio of 150 to $200 \%$.

\section{Nitrogen mass balance}

The daily average denitrification rate $\left[\mathrm{r}_{\mathrm{x}, \text { denit }}\right.$ expressed in $\mathrm{mg} \mathrm{N}$. ( MLVSS.h) ${ }^{-1}$ ] was calculated from 24 h nitrogen mass balances. This calculation was used for the WWTPs for which the effluent $\mathrm{NO}_{3}^{-}-\mathrm{N}$ concentration was above $1 \mathrm{~g} \mathrm{~N} \cdot \mathrm{m}^{-3}$ in the effluent. The calculation is based on the inflow rate and the concentrations measured in daily flow proportional composite samples (TKN, $\mathrm{NH}_{4}^{+}-\mathrm{N}, \mathrm{NO}_{3}^{-}-\mathrm{N}, \mathrm{BOD}_{5}$ ) in the influent and in the effluent.

Considering that the assimilated nitrogen flux $\left(\varphi_{\text {Ass }}\right)$ represents $5 \%$ of the removed $\mathrm{BOD}_{5}$ flux (Henze et al., 1996) the daily amount of nitrogen denitrified $\left(\varphi_{\text {denitrified }}\right)$ is calculated with a nitrogen mass balance, using the values of the influent and effluent TKN loads $\left(\varphi_{\text {TKN in }}, \varphi_{\text {TKN out }}\right)$, and the influent and effluent nitrate loads $\left(\varphi_{\mathrm{NO} 3 \text { in }}, \varphi_{\mathrm{NO} 3 \text { out }}\right)$. The daily average denitrification rate $\left(\mathrm{r}_{\mathrm{x} \text {, denit }}\right)$ is obtained by dividing $\varphi_{\text {denitrified }}\left(\mathrm{kgN} \cdot \mathrm{d}^{-1}\right)$ by the anoxic time (equal to ' $24 \mathrm{~h}$ - aerobic time', by the volume of the biological tanks (V), and by the mixed liquor concentration (MLVSS) in the biological tank. Equation (1) below provides the average denitrification rate over the entire biological stage, whether it consists of one or two tanks. 


$$
\begin{aligned}
r_{X, \text { denit }} & =\frac{\varphi_{\text {denitrified }}}{\text { MLVSS.V.(24- } \left.D_{\text {aerobic }}\right)} \\
& =\frac{\varphi_{\text {TKNin }}-\varphi_{\text {Ass }}-\varphi_{\text {TKNout }}+\varphi_{\text {NO3in }}-\varphi_{\text {NO3out }}}{M L V S S . V .\left(24-D_{\text {aerobic }}\right)}
\end{aligned}
$$

where:

$\mathrm{r}_{\mathrm{x}, \text { denit }} \quad$ : daily average denitrification rate [mg N.(g MLVSS $\left.\cdot h)^{-1}\right]$

$\varphi \quad:$ nitrogen mass $\left[\mathrm{kg} \mathrm{N} \cdot \mathrm{d}^{-1}\right]$

Ass : assimilation process

TKN : Kjeldahl nitrogen $\left[\mathrm{g} \mathrm{N} \cdot \mathrm{m}^{-3}\right]$

$\mathrm{NO}_{3}:$ nitrates $\left[\mathrm{g} \mathrm{N} \cdot \mathrm{m}^{-3}\right]$

in : calculated in the influent

out : calculated in the effluent

$\mathrm{V} \quad$ : total volume of biological tanks $\left[\mathrm{m}^{3}\right]$

$\mathrm{D}_{\text {aerobic }}$ : daily aerobic time $\left[\mathrm{h} \cdot \mathrm{d}^{-1}\right]$

MLVSS : mixed liquor concentration in biological tank $\left[\mathrm{kg} \mathrm{MLVSS} \cdot \mathrm{m}^{-3}\right]$

Accuracy assessment: When the average daily nitrate concentration in the effluent is above $1 \mathrm{~g} \mathrm{NO}_{3}^{-}-\mathrm{N} \cdot \mathrm{m}^{-3}$, there are some periods for which the denitrification rate in the reactor can include some anaerobic time $\left(\mathrm{NO}_{3}^{-}-\mathrm{N}\right.$ concentration $\left.=0\right)$ into the anoxic periods. When the aerobic time $\left(\mathrm{D}_{\text {aerobic }}\right)$ is lower than $13 \mathrm{~h} \cdot \mathrm{d}^{-1}$, an over-estimation of $\mathrm{D}_{\text {anoxic }}$ by $5 \%$ induces, provokes an error on the denitrification rate estimation $\left(\mathrm{r}_{\mathrm{x} \text {, denit }}\right)$ lower than $5 \%$. For $\mathrm{D}_{\text {aerobic }}>15 \mathrm{~h} \cdot \mathrm{d}^{-1}$, the nitrate concentration in the effluent is generally higher than $5 \mathrm{gN} \cdot \mathrm{m}^{-3}$, preventing anaerobic conditions from occurring during un-aerated periods. For $\mathrm{D}_{\text {aerobic }}$ in the range 13 to $15 \mathrm{~h} \cdot \mathrm{d}^{-1}$, the error on the denitrification rate estimation is lower than $10 \%$.

\section{Simulations with original and modified ASM1 matrix}

A modification of ASM1 for implementing a reduced value of $\mathrm{Y}_{\mathrm{H}}$ under anoxic conditions was performed ( $\left.\mathrm{Y}_{\mathrm{H} \text {, anoxic }}\right)$. It comprised substituting the single $\mathrm{Y}_{\mathrm{H}}$ yield value used in the aerobic and anoxic growth equations of heterotrophic bacteria (Henze et al., 1987) by two different values for anoxic and aerobic conditions respectively: $\mathrm{Y}_{\mathrm{H} \text {, anoxic }}=0.54 \mathrm{gCOD}_{\text {produced }} / \mathrm{gCOD}_{\mathrm{r}}$ (anoxic growth equation), and $\mathrm{Y}_{\mathrm{H}, \text { aer }}=0.67 \mathrm{gCOD}_{\text {produced }} / \mathrm{gCO}$ $\mathrm{D}_{\text {removed }}$ (aerobic growth equation).

Two configurations (single aeration tank and pre-denitrification layout - Fig. 1) were used to perform the simulations. Biological processes in the reactors were simulated with the original ASM1 matrix (single $Y_{H}$ ) and with the modified matrix (dual $\mathrm{Y}_{\mathrm{H}}$ ). To simulate the sludge mass contained in the clarifier, the 10-layer non-reactive settling model (Takacs et al., 1991) was used.

The design of each virtual layout was chosen to represent the conventional design $\mathrm{F} / \mathrm{M}$ ratio below $0.1 \mathrm{~kg} \mathrm{BOD} \cdot(\mathrm{kg}$ MLVSS $\cdot)^{-1}$. The biological tank volume was equal in both configurations. In the case of the pre-denitrification layout, the anoxic zone represented $20 \%$ of the total biological volume, with a mixed liquor return ratio of 150 to $200 \%$. When the nitrate concentration is lower than $5 \mathrm{~g} \mathrm{~N} \cdot \mathrm{m}^{-3}$ there is no influence of the recycle ratio. For a nitrate concentration of over $5 \mathrm{~g} \mathrm{~N} \cdot \mathrm{m}^{-3}$ in the effluent, a modification of the recycle ratio between 150 and $200 \%$ has little impact on the denitrification performance in the pre-denitrification tank.

The daily average effluent nitrogen concentrations were predicted by simulating three SRTs. The daily aerobic times used in the simulations ranged from 9 to $24 \mathrm{~h}$. For both configurations, $3 \mathrm{~F} / \mathrm{M}$ ratios were studied (Table 1): (i) Single aeration tank layout:

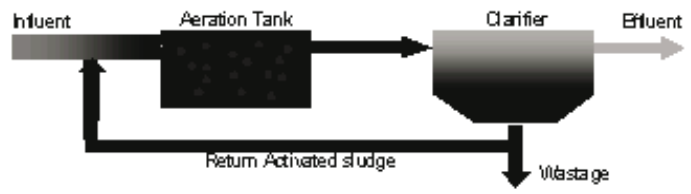

(ii) Pre-denitrification layout:

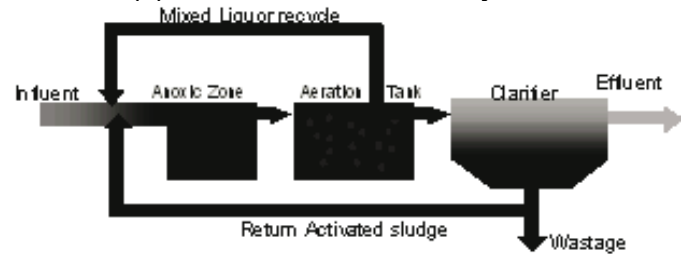

Figure 1

Virtual layouts (single aeration tank and pre-denitrification layouts) used to perform the simulations

TABLE 1

Simulated operation conditions

\begin{tabular}{|l|l|c|c|c|}
\hline & Unit & Run 1 & Run 2 & Run 3 \\
\hline F/M & $\mathrm{kg} \mathrm{BOD}_{5} \cdot(\mathrm{kg} \mathrm{MLVSS} \cdot \mathrm{d})^{-1}$ & 0.03 & 0.07 & 0.15 \\
\hline MLTSS & $\mathrm{kg} \cdot \mathrm{m}^{-3}$ & 5.6 & 2.4 & 4.2 \\
\hline SRT & $\mathrm{d}$ & 68 & 26 & 11 \\
\hline
\end{tabular}

- $\quad 0.03 \mathrm{kgBOD}_{5} \cdot(\mathrm{kg} \text { MLVSS } \cdot \mathrm{d})^{-1}$ (Run 1$)$ and $0.07 \mathrm{~kg} \mathrm{BOD} \cdot(\mathrm{kg}$ MLVSS $\cdot d)^{-1}$ (Run 2), changing the sludge concentration through wastage (5.6 and $2.4 \mathrm{~kg}$ MLTSS $\cdot \mathrm{m}^{-3}$ respectively), i.e. changing the sludge age of the system, while the influent loads were kept constant. Corresponding to the lowest and highest $\mathrm{F} / \mathrm{M}$ ratios in the group of surveyed plants, Runs 1 and 2 aim at comparing the simulated effluent concentrations of both layouts with those measured on site, in order to validate the modification of $\mathrm{Y}_{\mathrm{H}}$.

- $\quad 0.15 \mathrm{~kg} \mathrm{BOD}_{5} \cdot(\mathrm{kg} \mathrm{MLVSS} \cdot \mathrm{d})^{-1}$ (Run 3) at $4.2 \mathrm{~kg} \mathrm{MLTSS} \cdot \mathrm{m}^{-3}$, increasing the influent load. Run 3 aims at comparing the simulated performance of both layouts at an F/M ratio of $50 \%$ higher than the conventional design guideline to assess the relevance of pre-denitrification layout in a range where no full-scale data are available.

During the aerobic phase, the oxygen supply was controlled with a DO set point of $2.4 \mathrm{gO}_{2} \cdot \mathrm{m}^{-3}$ which corresponds to the average observed concentration on low loaded activated sludge treatment plants. Typical concentrations and fractionation of munici-

\begin{tabular}{|c|c|c|c|}
\hline \multicolumn{4}{|c|}{$\begin{array}{c}\text { TABLE } 2 \\
\text { Simulated and observed influent characteristics }\end{array}$} \\
\hline $\begin{array}{l}\text { Para- } \\
\text { meter }\end{array}$ & Unit & $\begin{array}{l}\text { Simulated influent } \\
\text { concentrations }\end{array}$ & $\begin{array}{l}\text { Observed influ- } \\
\text { ent concentra- } \\
\text { tions (22 full- } \\
\text { scale WWTPs) }\end{array}$ \\
\hline COD & $\mathrm{gO}_{2} \cdot \mathrm{m}^{-3}$ & $\begin{array}{l}500 \\
S s=20 \% ; X s=59 \% \\
S i=4 \% ; X i=17 \%\end{array}$ & $500 \pm 180$ \\
\hline $\mathrm{BOD}_{5}$ & $\mathrm{gO}_{2} \cdot \mathrm{m}^{-3}$ & 200 & $220 \pm 100$ \\
\hline TKN & $\mathrm{gN} \cdot \mathrm{m}^{-3}$ & 41.6 & $43 \pm 14$ \\
\hline $\mathrm{NH}_{4}^{+}-\mathrm{N}$ & $\mathrm{gN} \cdot \mathrm{m}^{-3}$ & 29.6 & $28 \pm 12$ \\
\hline
\end{tabular}
pal wastewater were used for the simulations (Table 2). These 


\begin{tabular}{|c|c|c|}
\hline \multicolumn{3}{|c|}{$\begin{array}{c}\text { TABLE } 3 \\
\text { Parameter values at } 10^{\circ} \mathrm{C} \text { used in the } \\
\text { simulations }\end{array}$} \\
\hline Parameter & Unit & Value \\
\hline \multicolumn{3}{|c|}{ Stoichiometric parameter } \\
\hline $\begin{array}{l}\left.\mathrm{Y}_{\mathrm{H}} \text { (original matrix }\right) \\
\mathrm{Y}_{\mathrm{H}, \text { aer }}(\text { modified matrix })\end{array}$ & $g X_{B H} \cdot g C O D^{-1}$ & 0.67 \\
\hline $\mathrm{Y}_{\mathrm{H}, \text { anoxic }}$ & $g X_{B H} \cdot g C O D^{-1}$ & 0.54 \\
\hline $\mathrm{Y}_{\mathrm{A}}$ & $g X_{B A} \cdot g N n i t^{I}$ & 0.24 \\
\hline$f_{p}$ & - & 0.08 \\
\hline$i_{X B}$ & $g N \cdot g C O D^{-1}$ & 0.086 \\
\hline $\mathrm{i}_{\mathrm{XP}}$ & $g N \cdot g C O D^{-1}$ & 0.060 \\
\hline \multicolumn{3}{|c|}{ Kinetic parameter $\left(10^{\circ} \mathrm{C}\right)$} \\
\hline \multicolumn{3}{|l|}{ Heterotrophic biomass } \\
\hline$\mu_{\mathrm{H}, \max }$ & $d^{-1}$ & 3.0 \\
\hline $\mathrm{b}_{\mathrm{H}}$ & $d^{-1}$ & 0.47 \\
\hline $\mathrm{K}_{\mathrm{O}, \mathrm{H}}$ & $g \mathrm{O}_{2} \cdot m^{-3}$ & 0.05 \\
\hline $\mathrm{K}_{\mathrm{NO}}$ & $g \mathrm{NO}_{3}{ }^{-}-N \cdot m^{-3}$ & 0.10 \\
\hline $\mathrm{k}_{\mathrm{a}}$ & $m^{3} \cdot g C O D^{-1} \cdot d^{-1}$ & 0.04 \\
\hline $\mathrm{K}_{\mathrm{s}}$ & $g C O D \cdot m^{-3}$ & 20.0 \\
\hline $\mathrm{K}_{\mathrm{x}}$ & $g X s \cdot g X_{B H}^{-1}$ & 0.03 \\
\hline $\mathrm{k}_{\mathrm{h}}$ & $g X s \cdot g X_{B H}{ }^{-1} \cdot d^{-1}$ & 1.5 \\
\hline$\eta_{\mathrm{g}}$ & - & 0.80 \\
\hline$\eta_{\mathrm{h}}$ & - & 0.40 \\
\hline \multicolumn{3}{|l|}{ Autotrophic biomass } \\
\hline$\mu_{\mathrm{A}, \max }$ & $d^{-1}$ & 0.45 \\
\hline $\mathrm{b}_{\mathrm{A}}$ & $d^{-1}$ & 0.13 \\
\hline $\mathrm{K}_{\mathrm{NH}}$ & $g N H_{4}^{+}-N \cdot m^{-3}$ & 0.10 \\
\hline $\mathrm{K}_{\mathrm{O}, \mathrm{A}}$ & $g \mathrm{O}_{2} \cdot m^{-3}$ & 0.20 \\
\hline
\end{tabular}

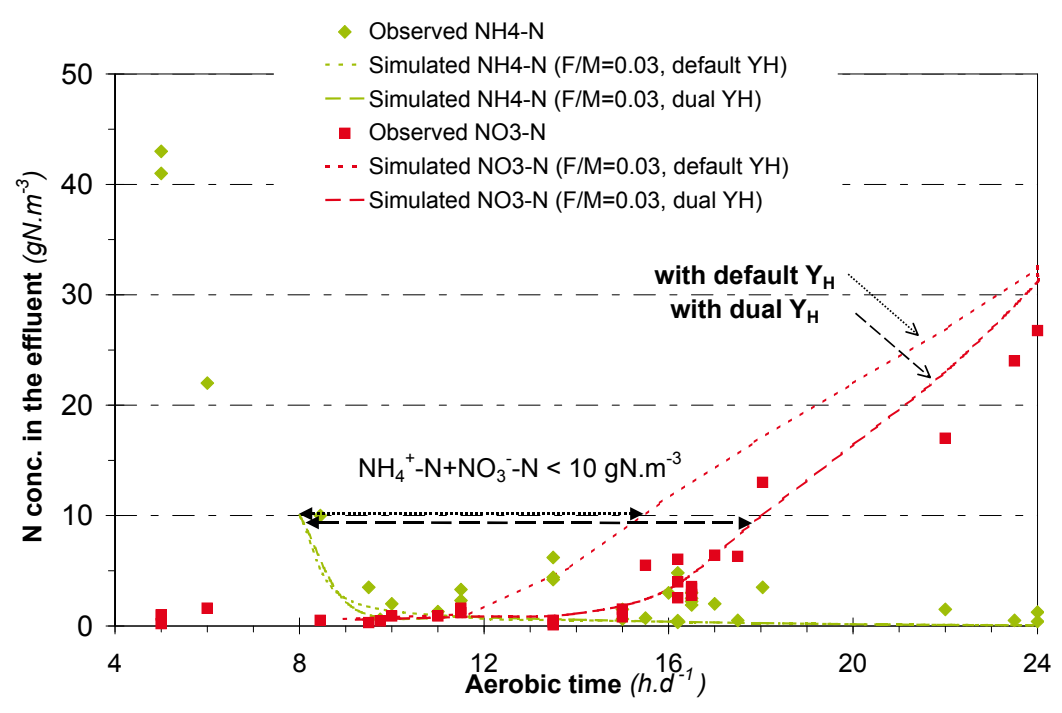

Figure 2(a)

Nitrogen concentrations in the effluent VS aerobic time (single aeration tank, $10^{\circ} \mathrm{C}$ ) - Observed vs. simulated values (Run $1, F / M=0.03 \mathrm{~kg}$ $\left.B O D_{5} \cdot(k g M L V S S \cdot d)^{-1}\right)$

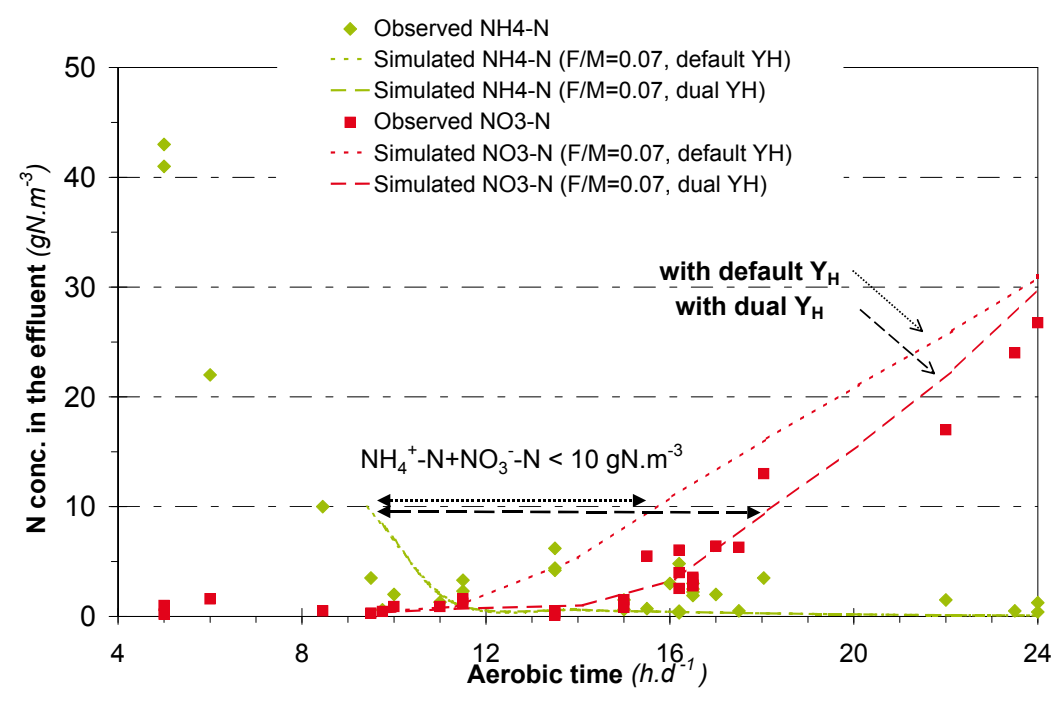

values were chosen from the average concentrations calculated from data recorded on the 22 full-scale WWTPs.

The kinetic parameters used in the simulations at $10^{\circ} \mathrm{C}$ are listed in Table 3 . The parameters consist of the default values proposed by Henze et al. (1987), updated with recent results on growth and decay rates reported by Dold (2005), Marquot (2006) and Choubert (2008).

\section{Results and discussion}

The nitrogen concentrations measured in the effluent of the 22 WWTPs were compared to those obtained with both the original and modified ASM1 matrices. The need to use a reduced value for the heterotrophic anoxic yield in anoxic conditions is demonstrated. The performances obtained with the pre-denitrification tank are compared to those observed with a single tank in order to support the design decision procedure.

\section{Case of single tank configuration}

Figures 2(a) and 2(b) show the nitrogen concentrations in the effluent vs. the aerobic time for the 13 single tank WWTPs operated at $\mathrm{F} / \mathrm{M}$ ratios ranging from 0.03 to $0.07 \mathrm{kgBOD}_{5} \cdot(\mathrm{kg}$ MLVSS $\cdot d)^{-1}$ respectively. Simulated concentrations obtained with the original ASM1 (single $\mathrm{Y}_{\mathrm{H}}$ ), and the modified ASM1 (dual anoxic/aerobic $\mathrm{Y}_{\mathrm{H}}$ ) are presented.

The simulated $\mathrm{NH}_{4}^{+}-\mathrm{N}$ effluent concentrations are in good agreement with those observed. For an $\mathrm{F} / \mathrm{M}$ ratio $=$ $0.07 \mathrm{kgBOD}_{5} \cdot(\mathrm{kg} \mathrm{MLVSS} \cdot \mathrm{d})^{-1}$, a minimum daily aerobic time of $10 \mathrm{~h} \cdot \mathrm{d}^{-1}$ is observed. It is necessary to maintain the $\mathrm{NH}_{4}^{+}-$ $\mathrm{N}$ concentration in the effluent lower than $2 \mathrm{gN} \cdot \mathrm{m}^{-3}$, whereas a $8 \mathrm{~h} \cdot \mathrm{d}^{-1}$ window is necessary at $\mathrm{F} / \mathrm{M}$ ratio $=0.03 \mathrm{kgBOD}_{5} \cdot(\mathrm{kg}$ MLVSS $\cdot \mathrm{d})^{-1}$. That confirms the theoretical value recommended by practitioners (FNDAE_25, 2002).

For daily aerobic time lower than $12 \mathrm{~h} \cdot \mathrm{d}^{-1}$, the simulated nitrate concentrations fit to measurements for both $\mathrm{Y}_{\mathrm{H}}$ values, 
and there is low nitrate concentration $\left(2 \mathrm{~g} \mathrm{NO}_{3}^{-}-\mathrm{N} \cdot \mathrm{m}^{-3}\right)$ in the effluent. When the daily aerobic time is higher than $12 \mathrm{~h} \cdot \mathrm{d}^{-1}$, the simulated nitrate concentrations with a single $Y_{H}$ are higher than the observed values: Approximately $10 \mathrm{gN} \cdot \mathrm{m}^{-3}$ higher at $16 \mathrm{~h} \cdot \mathrm{d}^{-1}$. The use of the modified ASM1 (anoxic/aerobic $\mathrm{Y}_{\mathrm{H}}$ ) leads to a lower simulated nitrate concentration (approximately $10 \mathrm{~g} \mathrm{~N} \cdot \mathrm{m}^{-3}$ at $16 \mathrm{~h} \cdot \mathrm{d}^{-1}$ ) up to an aerobic time of $23 \mathrm{~h} \cdot \mathrm{d}^{-1}$. Simulated nitrate concentrations in the effluent are in far better agreement with measured values. No difference can be observed between simulated nitrate concentrations at $\mathrm{F} / \mathrm{M}$ ratios $=0.03 \mathrm{~kg} \mathrm{BOD} \cdot \cdot \mathrm{kg}$ MLVSS $\cdot \mathrm{d})^{-1}$ (Run 1) and $0.07 \mathrm{~kg} \mathrm{BOD} \cdot \cdot \mathrm{kg}$ MLVSS $\left.\cdot \mathrm{d}\right)^{-1}$ (Run 2).

From the $\mathrm{NH}_{4}^{+}{ }_{-} \mathrm{N}$ concentrations simulated with $\mathrm{F} / \mathrm{M}$ ratio $=0.07 \mathrm{~kg} \mathrm{BOD} \cdot \mathrm{kg}$ MLVSS $\cdot \mathrm{d})^{-1}$ (Fig. $2 \mathrm{~b}-$ Run 2), it can be concluded that any daily aerobic time in the range of 10 to $18 \mathrm{~h} \cdot \mathrm{d}^{-1}$ ( $8 \mathrm{~h}$-window) is adequate to maintain the combined $\mathrm{NH}_{4}^{+}-\mathrm{N}^{-}$and $\mathrm{NO}_{3}^{-}-\mathrm{N}$ concentration below $10 \mathrm{~g} \mathrm{~N} \cdot \mathrm{m}^{-3}$, with a $\mathrm{NH}_{4}^{+}-\mathrm{N}$ concentration below $2 \mathrm{~g} \mathrm{~N} \cdot \mathrm{m}^{-3}$ in the effluent. The simulated results obtained with the single $\mathrm{Y}_{\mathrm{H}}$ lead to a narrower range from $10 \mathrm{~h} \cdot \mathrm{d}^{-1}$ to $15 \mathrm{~h} \cdot \mathrm{d}^{-1}$ ( $5 \mathrm{~h}$ window).

For an F/M ratio of $0.03 \mathrm{~kg} \mathrm{BOD}{ }_{5} \cdot \mathrm{kg}$ MLVSS $\left.\cdot \mathrm{d}\right)^{-1}$ (Fig. 2a - Run 1) any daily aerobic time in the range 8 to $18 \mathrm{~h} \cdot \mathrm{d}^{-1}$ (10 h-window) is adequate to maintain both the sum of $\mathrm{NH}_{4}^{+}-\mathrm{N}$ and $\mathrm{NO}_{3}^{-}-\mathrm{N}$ concentrations below $10 \mathrm{gN} \cdot \mathrm{m}^{-3}$, with $\mathrm{NH}_{4}^{+}-\mathrm{N}$ concentrations below $2 \mathrm{gN} \cdot \mathrm{m}^{-3}$, in the effluent. The simulated results obtained with the single $\mathrm{Y}_{\mathrm{H}}$ lead to a narrower range from $8 \mathrm{~h} \cdot \mathrm{d}^{-1}$ to $15 \mathrm{~h} \cdot \mathrm{d}^{-1}(7 \mathrm{~h}$ window).

\section{Case of pre-denitrification tank configuration}

To estimate the contribution of an anoxic zone to denitrification, the $\mathrm{NO}_{3}^{-}-\mathrm{N}$ and $\mathrm{NH}_{4}{ }^{+}-\mathrm{N}$ concentrations measured in the effluent of WWTPs of the pre-denitrification configuration were studied as a function of the daily aerobic time in the aeration tank. Simulation results at $\mathrm{F} / \mathrm{M}=0.03$ (Run 1) and $0.07 \mathrm{kgBOD}_{5} \cdot \mathrm{kg}$ MLVSS $\cdot d)^{-1}$ (Run 2) are plotted on Fig. 3(a) and 3(b) respectively.

It is observed that the use of the modified ASM1 (anoxic/aerobic $\mathrm{Y}_{\mathrm{H}}$ ) provides a lower simulated nitrate concentration (approximately $10 \mathrm{~g} \mathrm{~N} \cdot \mathrm{m}^{-3}$ at $16 \mathrm{~h} \cdot \mathrm{d}^{-1}$ ) even up to an aerobic time of $24 \mathrm{~h}$ a day due to the predenitrification tank contribution.

For an $\mathrm{F} / \mathrm{M}$ ratio of $0.07 \mathrm{~kg} \mathrm{BOD}{ }_{5} \cdot(\mathrm{kg} \mathrm{MLVSS} \cdot \mathrm{d})^{-1}$, the sum of $\mathrm{NH}_{4}^{+}-\mathrm{N}$ concentrations and $\mathrm{NO}_{3}^{-}-\mathrm{N}$ concentrations can be maintained below $10 \mathrm{~g} \mathrm{~N} \cdot \mathrm{m}^{-3}$ in the effluent with $\mathrm{NH}_{4}{ }^{+}-\mathrm{N}$ below $2 \mathrm{gN} \cdot \mathrm{m}^{-3}$, for any aerobic time in the range of $12 \mathrm{~h} \cdot \mathrm{d}^{-1}$ to $24 \mathrm{~h} \cdot \mathrm{d}^{-1}$ (12 $\mathrm{h}$ window). An aerobic time range of 10 to $24 \mathrm{~h} \cdot \mathrm{d}^{-1}(14 \mathrm{~h}$ window) is possible for an $\mathrm{F} / \mathrm{M}$ ratio of $\left.0.03 \mathrm{~kg} \mathrm{BOD}{ }_{5} \cdot \mathrm{kg} \mathrm{MLVSS} \cdot \mathrm{d}\right)^{-1}$. These 'windows' are $4 \mathrm{~h}$ longer than those determined for the single aeration tank configuration. For an aerobic time over $18 \mathrm{~h} \cdot \mathrm{d}^{-1}$, the pre-denitrification layout allows lower nitrate concentrations than those obtained with the single aeration tank configuration, which is expected, because the un-aerated mass fraction is effectively increased. For a lower aeration time value the pre-denitrification layout does not allows lower nitrate

Figure 4 (right)

Average denitrification rate vs. F/M ratio for single aeration tank configuration and pre-denitrification layout

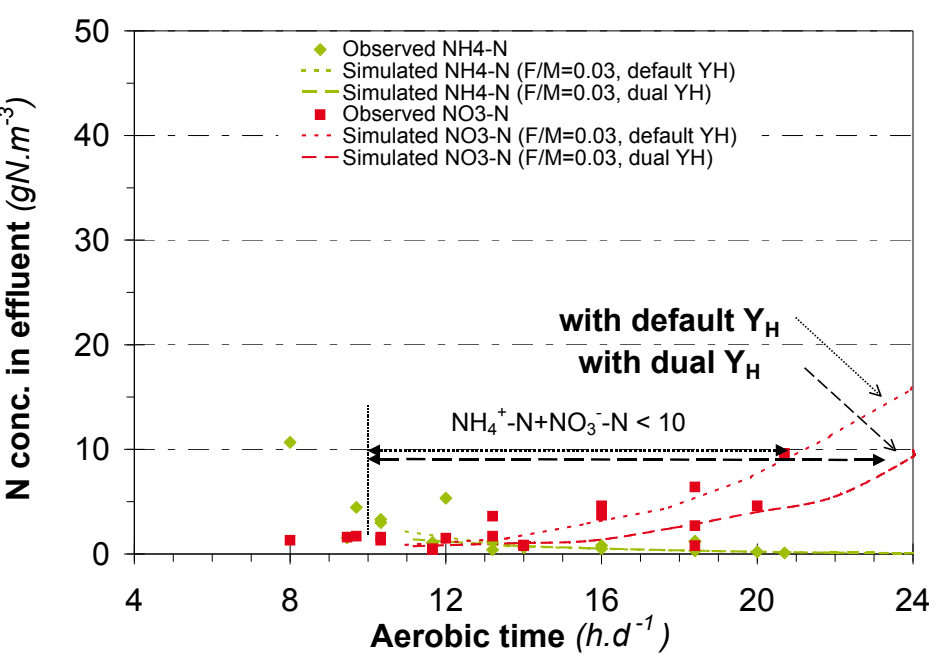

Figure 3(a)

itrogen concentrations in the effluent vs. aerobic time (pre-denitrification layout, $10^{\circ} \mathrm{C}$ ) - Observed vs. simulated values (Run 1, F/M $=0.03 \mathrm{~kg}$ $\left.B O D_{5} \cdot(\mathrm{kg} \mathrm{MLVSS} \cdot d)^{-1}\right)$

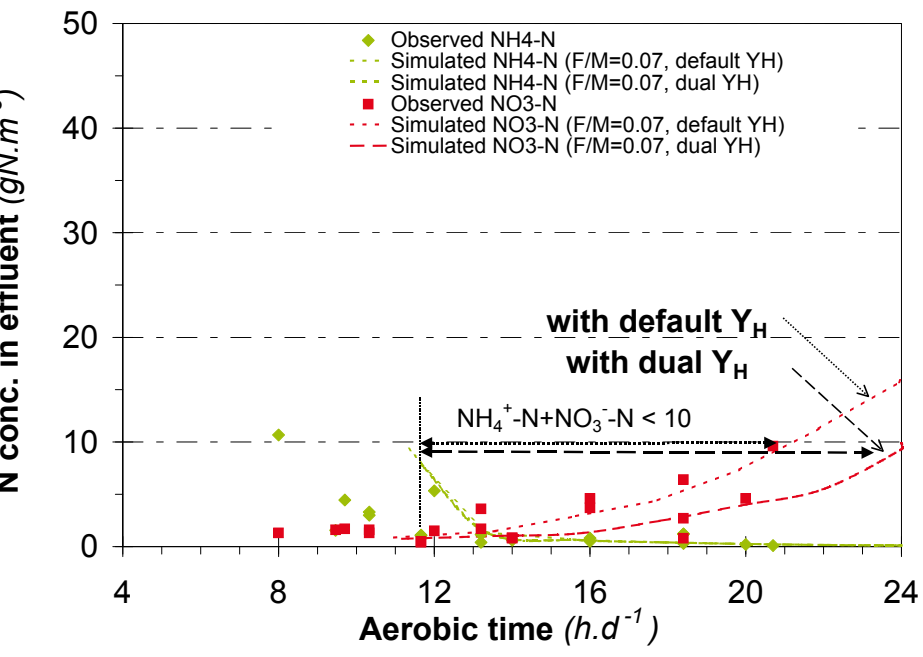

Figure 3(b)

itrogen concentrations in the effluent vs. aerobic time (pre-denitrification layout, $10^{\circ} \mathrm{C}$ ) - Observed vs. simulated values (Run 2, $F / M=0.07 \mathrm{~kg}$ $\left.B O D_{5} \cdot(k g ~ M L V S S \cdot d)^{-1}\right)$

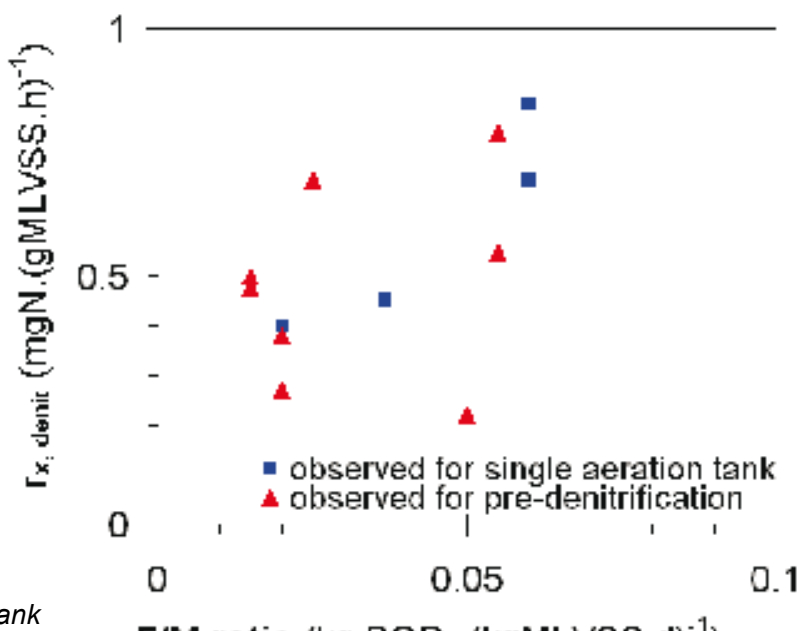

F/M ratio (kg BOD $\left.{ }_{\sigma}\left(\mathrm{kgMLVSS}^{-\mathrm{d}}\right)^{-1}\right)$ 


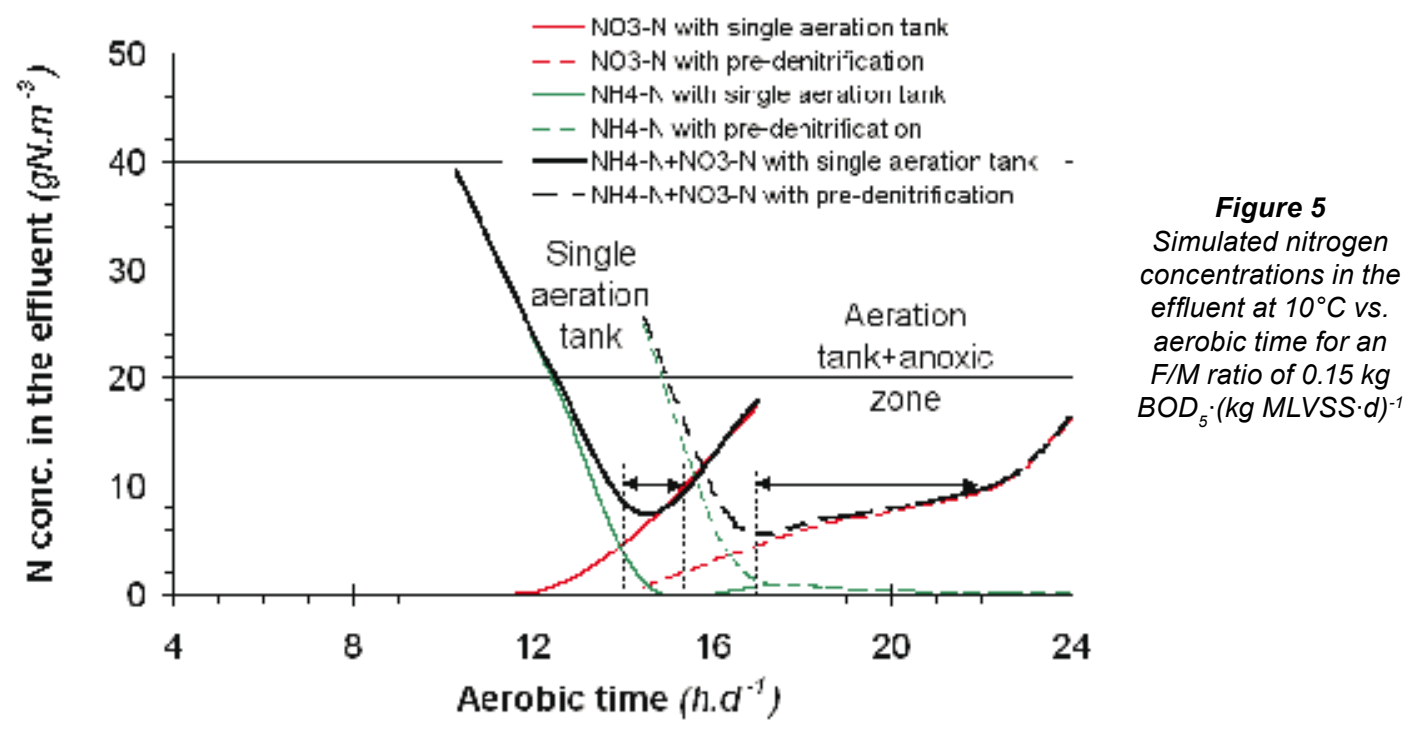

concentrations. But at such low $\mathrm{F} / \mathrm{M}$ ratios, no more ammonium can be nitrified since the concentration in the effluent is below $1 \mathrm{~g} \mathrm{~N} \cdot \mathrm{m}^{-3}$.

The daily average denitrification rates calculated from the mass balance on the overall biological stage (Eq. (1)) vs. F/M ratio for both single aeration tank and pre-denitrification layouts are presented in Fig. 4. Similar denitrification rates were observed for both layouts: 0.4 to $0.5 \mathrm{mg} \mathrm{N} \cdot(\mathrm{g} \text { MLVSS} \cdot h)^{-1}$ at $\mathrm{F} / \mathrm{M}$ ratio $=$ $0.02 \mathrm{~kg} \mathrm{BOD}{ }_{5} \cdot \mathrm{kg}$ MLVSS $\left.\cdot \mathrm{d}\right)^{-1}$; and 0.7 to $0.8 \mathrm{mg} \mathrm{N} \cdot \mathrm{g}$ MLVSS $\left.\cdot \mathrm{h}\right)^{-1}$ at $\mathrm{F} / \mathrm{M}$ ratio $=0.06 \mathrm{~kg} \mathrm{BOD} \cdot \cdot \mathrm{kg}$ MLVSS $\cdot \mathrm{d})^{-1}$. Low concentrations of readily biodegradable COD in the mixed liquor could be responsible for the values observed at low $\mathrm{F} / \mathrm{M}$ ratios.

From the data observed on the 22 full-scale plants operated at $\mathrm{F} / \mathrm{M}$ ratio $<0.07 \mathrm{~kg} \mathrm{BOD} \cdot \cdot \mathrm{kg}$ MLVSS $\cdot \mathrm{d})^{-1}$, it is shown that the pre-denitrification layout does not provide higher daily average denitrification rates than those observed with the single tank configuration. These observations confirm the poor contribution of the pre-denitrification tank configuration to nitrate removal (below 15\%) proposed by Lessard (2007). Nevertheless it is shown that the configuration allows a more flexible aerobic time 'window' to meet the nitrogen concentration targets, as soon as the $\mathrm{F} / \mathrm{M}$ ratios are lower than $\left.0.10 \mathrm{~kg} \mathrm{BOD}_{5} \cdot \mathrm{kg} \mathrm{MLVSS} \cdot \mathrm{d}\right)^{-1}$. These surplus aerobic conditions can unfortunately not increase nitrification capacity because ammonium is no longer available.

The contribution of the pre-denitrification tank was then investigated through simulations (Run 3) for an $\mathrm{F} / \mathrm{M}$ ratio $50 \%$ higher than the conventional design guideline recommended. The nitrogen concentrations simulated for both plant configurations with the modified ASM1 (anoxic/aerobic $\mathrm{Y}_{\mathrm{H}}$ ) at $\mathrm{F} / \mathrm{M}$ ratio $=0.15 \mathrm{~kg} \mathrm{BOD} \cdot \cdot \mathrm{kg} \mathrm{MLVSS} \cdot \mathrm{d})^{-1}$ were represented as a function of the aerobic time (Fig. 5).

At $\mathrm{F} / \mathrm{M}$ ratio $=0.15 \mathrm{~kg} \mathrm{BOD} \cdot \mathrm{kg}$ MLVSS $\cdot \mathrm{d})^{-1}$, simulation results show (Fig. 5) that a $\mathrm{NH}_{4}^{+}-\mathrm{N}$ concentration lower than 2 $\mathrm{g} \mathrm{N} \cdot \mathrm{m}^{-3}$ can be reached at $10^{\circ} \mathrm{C}$ when the aerobic time is higher than $14 \mathrm{~h} \cdot \mathrm{d}^{-1}$ for the single tank layout, and $17 \mathrm{~h} \cdot \mathrm{d}^{-1}$ for the predenitrification tank layout. These values are $30 \%$ higher than those obtained for an $\mathrm{F} / \mathrm{M}$ of $0.07 \mathrm{~kg} \mathrm{BOD}{ }_{5} \cdot(\mathrm{kg} \text { MLVSS } \cdot \mathrm{d})^{-1}(10$ and $12 \mathrm{~h} \cdot \mathrm{d}^{-1}$ respectively). The minimum daily aerobic time is higher for the pre-denitrification configuration $\left(17 \mathrm{~h} \cdot \mathrm{d}^{-1}\right)$ due to a $20 \%$-lower aerobic SRT.

The sum of the effluent $\mathrm{NH}_{4}^{+}-\mathrm{N}$ and $\mathrm{NO}_{3}^{-}-\mathrm{N}$ concentrations (TIN) should be maintained below $10 \mathrm{gN} \cdot \mathrm{m}^{-3}$ when the daily aerobic time is in the range of $14 \mathrm{~h} \cdot \mathrm{d}^{-1}$ to $15.5 \mathrm{~h} \cdot \mathrm{d}^{-1}(1.5 \mathrm{~h}$ window) for the single aeration tank configuration, and in the range of $17 \mathrm{~h} \cdot \mathrm{d}^{-1}$ to $22 \mathrm{~h} \cdot \mathrm{d}^{-1}$ (5 h window) for the pre-denitrification tank configuration. The optimal aerobic time window is $3.5 \mathrm{~h}$ longer than the one determined for the single aeration tank configuration, giving more operational flexibility. The simulated denitrification rate is higher in the configuration with an anoxic zone at $2.0 \mathrm{mg} \mathrm{N} \cdot(\mathrm{g} \text { MLVSS } \cdot \mathrm{h})^{-1}$ vs. 0.8 to $1.0 \mathrm{mg} \mathrm{N} \cdot(\mathrm{g} \text { MLVSS } \cdot h)^{-1}$ for the single aeration tank configuration. According to the simulations, the amount of oxygen required is the same for the 2 configurations. The difference lies in the sharing of air supply in time and space.

These observations suggest that the contribution of the anoxic zone to nitrate removal becomes more significant at a higher $\mathrm{F} / \mathrm{M}$ ratio than the conventional design guideline proposes. This additional contribution provides more efficient denitrification kinetic capacities, while the additional aerobic time can be effectively used for nitrification, and it can produce more nitrates.

\section{Conclusions}

This study confirms with full-scale data that a reduced value for $\mathrm{Y}_{\mathrm{H}}$ in anoxic conditions should be used to properly simulate the effluent nitrate concentrations. This modification lowers the predicted nitrate concentration in treated water by $10 \mathrm{~g} \mathrm{NO}-\mathrm{N} \cdot \mathrm{m}^{-3}$ for simulations of over-aerated plants (over $12 \mathrm{~h} \cdot \mathrm{d}^{-1}$ ).

Once this modification is implemented in ASM1, simulations allow to determine the optimal daily aerobic time range to maintain both $\mathrm{NH}_{4}^{+}-\mathrm{N}$ concentrations below $2 \mathrm{~g} \mathrm{~N} \cdot \mathrm{m}^{-3}$, and the sum of $\mathrm{NH}_{4}^{+}-\mathrm{N}$ and $\mathrm{NO}_{3}^{-}-\mathrm{N}$ concentrations below $10 \mathrm{~g} \mathrm{~N} \cdot \mathrm{m}^{-3}$ (nitrogen discharge objective). For $\mathrm{F} / \mathrm{M}=0.07 \mathrm{~kg} \mathrm{BOD}_{5} \cdot \mathrm{kg}$ MLVSS $\left.\cdot \mathrm{d}\right)^{-1}$, a daily aerobic time in the range of 10 to $18 \mathrm{~h} \cdot \mathrm{d}^{-1}$ was shown efficient for the single tank layout, whereas a range from 12 to $24 \mathrm{~h} \cdot \mathrm{d}^{-1}$ was obtained for the pre-denitrification tank layout. For $\mathrm{F} / \mathrm{M}=0.03 \mathrm{~kg} \mathrm{BOD} \cdot(\mathrm{kg} \mathrm{MLVSS} \cdot \mathrm{d})^{-1}$, the daily aerobic time 'window' is 8 to $18 \mathrm{~h} \cdot \mathrm{d}^{-1}$ for the single tank layout, and 10 to $24 \mathrm{~h} \cdot \mathrm{d}^{-1}$ for the pre-denitrification tank layout. For this range in organic loading rate, as all the ammonia is removed (concentration below $1 \mathrm{~g} \mathrm{~N} \cdot \mathrm{m}^{-3}$ for the $4 \mathrm{~h}$ extra aerobic time), it is concluded that a pre-anoxic zone only limits the nitrate concentration in the case of over-aerated WWTPs (aerobic time over 18 $\left.h \cdot d^{-1}\right)$. Besides, the overall average denitrification rates are very similar for both configurations (with or without an anoxic zone): 
0.4 to $0.5 \mathrm{mg} \mathrm{N} \cdot(\mathrm{g} \text { MLVSS } \cdot \mathrm{h})^{-1}$ at an $\mathrm{F} / \mathrm{M}$ ratio around $0.02 \mathrm{~kg}$ $\mathrm{BOD}_{5} \cdot(\mathrm{kg} \mathrm{MLVSS} \cdot \mathrm{d})^{-1}$; and 0.7 to $0.8 \mathrm{mg} \mathrm{N} \cdot(\mathrm{g} \text { MLVSS } \cdot h)^{-1}$ at an $\mathrm{F} / \mathrm{M}$ ratio around $0.06 \mathrm{~kg} \mathrm{BOD} \cdot(\mathrm{kg} \mathrm{MLVSS} \cdot \mathrm{d})^{-1}$.

When the $\mathrm{F} / \mathrm{M}$ is $50 \%$ higher than the conventional design load $\left(0.15 \mathrm{~kg} \mathrm{BOD} \cdot(\mathrm{kg} \mathrm{MLVSS} \cdot \mathrm{d})^{-1}\right)$, the contribution of the anoxic zone to the denitrification process appears more significant. This is expected as more COD is admitted directly into the pre-anoxic reactor, which makes more COD available for denitrification, leading to higher denitrification kinetic capacities, and improving the use of the extra aerobic time for nitrification. The optimum daily aerobic time is in the range of 17 to $22 \mathrm{~h} \cdot \mathrm{d}^{-1}$, that is a $3.5 \mathrm{~h}$ higher but also a wider window than for the single aeration tank configuration (14 to $\left.15.5 \mathrm{~h} \cdot \mathrm{d}^{-1}\right)$. These observations suggest that the contribution of the anoxic zone to nitrate removal becomes more significant at an $\mathrm{F} / \mathrm{M}$ ratio of $50 \%$ over the design guideline.

\section{Acknowledgements}

This research was financially supported by the French Agriculture Ministry (FNDAE fund). The authors would like to thank the technical Cemagref staff for having investigated the 22 WWTPs: Amillis, Benfeld, Boississe-le-roi, Bonnelles, Brumath, Changis-sur-marne, Erstein, Fontenay-Tressigny, Gouvernes, Hautot-sur-mer, Hoffen-Soultz-la-forêt, Larchant, Marmoutier, Meaux, Ménuires, Mouthe, Ribeauvillé, Schirmeck, Sélestat, Seltz, Septeuil, Zellwiller.

\section{References}

ATV-DVWK (2000) Dimensioning of single-stage activated sludge plants. German Association of Water, Wastewater and Waste. DWA publisher. ISBN 978-3-935669-96-2, vol. A_131E. 54 pp.

CARRERA J, BAEZA JA, VICENT T and LAFUENTE J (2003) Biological nitrogen removal of high-strength ammonium industrial wastewater with two-sludge system. Water Res. 37 4211-4221.

CHOUBERT JM, MARQUOT A, STRICKER AE, GILLOT S, RACAULT Y and HÉDUIT A (2008) Maximum growth and decay rates of autotrophic biomass to simulate nitrogen removal at $10^{\circ} \mathrm{C}$ with municipal activated sludge plants. Water $S A 34$ (1) 71-76. http://www.wrc.org.za/downloads/watersa/2008/2119.pdf.

CHOUBERT JM, RACAULT Y, GRASMICK A, BECK C and HÉDUIT A (2005a) Maximum nitrification rate in activated sludge processes at low temperature: key parameters, optimal value. E-Water(Official Publication of the European Water Association) (EWA) $13 \mathrm{pp}$. http://www.ewaonline.de/journal/2005_09.pdf (Accessed $2^{\text {nd }}$ April 2008).

CHOUBERT JM, RACAULT Y, GRASMICK A, BECK C, HEDUIT A (2005b) Nitrogen removal from urban wastewater by activated sludge process operated over the conventional carbon loading rate limit at low temperature. Water $S A 31$ (4) 503-510. http://www.wrc. org.za/downloads/watersa/2005/Oct-05/1792.pdf.

DOLD PL, JONES RM and BYE CM (2005) Importance and measurement of decay rate when assessing nitrification kinetics. Water Sci. Technol. 52 (10-11) 469-477.

ELEFSINIOTIS P and LI D (2006) The effect of temperature and carbon source on denitrification using volatile fatty acids. Biochem. Eng. J. 28 148-155.
EUROPEAN DIRECTIVE 91/271/EEC (1991) Urban wastewater treatment. http://europa.eu.int/comm/environment/water/waterurban-waste/directiv.html (Accessed on 2nd April 2008).

FNDAE_ 25 (2002) Traitement de l'azote dans les stations d'épuration biologique des petites collectivités. FNDAE édition, Document Technique 25. 96 pp. http://www.eau.fndae.fr/documentation/ numero_25.htm (Accessed on $2^{\text {nd }}$ April 2008).

FOGLAR L and BRISKI F (2003) Wastewater denitrification process - The influence of methanol and kinetic analysis. Proc. Biochem. 39 95-103.

GUJER W, HENZE M, MINO T and VAN LOOSDRECHT MCM (1999) Activated Sludge Model Nº3. Water Sci. Technol. 39 (1) 183-193.

HENZE M, GRADY CPL, GUJER W, MARAIS GvR and MATSUO T (1987) Activated Sludge Model $N^{\circ} 1$. Scientific and Technical Report (IWA Publishing). 33 pp.

HENZE M, HARREMOËS P, LA COUR JANSEN J and ARVIN A (1996) Wastewater Treatment. Biological and Chemical Processes. Springer-Verlag, London 383 pp.

HENZE M, GRADY CPLJ, GUJER W, MARAIS GvR and MATSUO T (2000) Activated Sludge Models ASM1, ASM2D and ASM3. Scientific and Technical Report (IWA Publishing, London). 130 pp.

HOFFMAN E and KLUTE R (1990) Improving the denitrification potential in biological wastewater treatment by dosing carbon from sludge hydrolysis. In: HH Hahn and R Klute (eds.) Chemical Water and Wastewater Treatment. Springer-Verlag, Berlin.

JIANG T, LIU X, KENNEDY MD, SCHIPPERS JC, VANROLLEGHEM PA (2005) Calibrating a side-stream membrane bioreactor using Activated Sludge Model No. 1. Water Sci. Technol. 52 (10-11) 359-367.

MARQUOT A, STRICKER AE and RACAULT Y (2006) ASM1 dynamic calibration and long-term validation for an intermittently aerated WWTP. Water Sci. Technol. 53 (12) 247-256.

LESSARD P, TUSSEAU-VUILLEMIN MH, HÉDUIT $A$ and LAGARDE F (2007) Assessing chemical oxygen demand and nitrogen conversions in a multi-stage activated sludge plant with alternating aeration. J. Chem. Technol. Biotechnol. 82 367-375.

METCALF \& EDDY ( $4^{\text {th }}$ edn.) Revised by Tchobanoglous G, Burton, FL and Stensel D (2005) Wastewater Engineering Treatment and Reuse. McGraw-Hill, New York. 1875 pp.

MULLER A, WENTZEL MC, LOEWENTHAL RE and EKAMA G (2003) Heterotroph anoxic yield in anoxic aerobic sludge systems treating municipal wastewater. Water Res. 37 (10) 2435-2441.

ORHON D, HANHAN O, GÖRGÜN E and SÖZEN S (1998) A unified basis for the design of nitrogen removal activated sludge process the Braunschweig exercise. Water Sci. Technol. 38 (1) 227-236.

SOZEN S, COKGOR EU, ORHON D and HENZE M (1998) Respirometric analysis of activated sludge behaviour-II Heterotrophic growth under aerobic and anoxic conditions. Water Res. 37 (10) 2435-2441.

SPERANDIO M and ESPINOSA M C (2008) Modelling an aerobic submerged membrane bioreactor with ASM models on a large range of sludge retention time. Desalination 231 (1-3) 82-90.

SPERANDIO M, URBAIN V, AUDIC JM and PAUL E (1999) Use of carbon dioxide evolution rate for determining heterotrophic yield and characterizing denitrifying biomass. Water Sci. Technol. 39 (1) 139-146.

STROTMANN UJ, GELDERN A, KUHN A, GENDING C and LEIN $S$ (1999) Evaluation of a respirometric test method to determine the heterotrophic yield coefficient of activated sludge bacteria. Chemosphere 38 (15) 3555-3570.

TAKACS I, PATRY GG and NOLASCO D (1991) A dynamic model of the clarification-thickening process. Water Res. 25 (10) 1263-1271. 
Available on website http://www.wrc.org.za ISSN 0378-4738 = Water SA Vol. 35 No. 1 January 2009

ISSN 1816-7950 = Water SA (on-line) 